ПЕДАГОГИКА

DOI: 10.17805/trudy.2016.6.1

\title{
НАУЧНЫЕ ПРИОРИТЕТЫ \\ КАФЕДРЫ ПЕДАГОГИКИ И ПСИХОЛОГИИ ВЫСШЕЙ ШКОЛЫ МОСКОВСКОГО ГУМАНИТАРНОГО УНИВЕРСИТЕТА
}

\author{
В. А. Ситаров. Л. В. Романюк \\ (Московский гуманитарный университет)
}

Аннотация: В статье представлена научная школа Московского гуманитарного университета по педагогике и психологии высшей школы.

Ключевые слова: научная школа; Московский гуманитарный университет; кафедра; педагогика и психология высшей школы; обзор

\section{THE SCIENTIFIC PRIORITIES OF THE DEPARTMENT OF PEDAGOGY AND PSYCHOLOGY OF HIGHER SCHOOL OF THE MOSCOW UNIVERSITY FOR THE HUMANITIES}

\author{
V.A. Sitarov, L.V. Romanyuk \\ (Moscow University for the Humanities)
}

\begin{abstract}
The article presents the scientific school of Moscow University for the Humanities in pedagogy and psychology of higher school.

Keywords: scientific school; Moscow University for the Humanities; Department; pedagogy and psychology of higher school; review
\end{abstract}

На кафедре педагогики и психологии высшей школы Московского гуманитарного университета сложилась оригинальная научная школа, ориентированная на инновационный путь развития высшего гуманитарного образования. Реализуя концептуальную идею о воспитании жизнеспособного поколения, выдвинутую и разработанную доктором философских наук, профессором И. М. Ильинским (Ильинский, 1995, 2001), кафедра ведет научный поиск содержания и педагогических технологий, позволяющих обеспечить способность выпускников университета к творческой самореализации, профессиональной компетентности в области психолого- 
педагогического образования (Ситаров, Романюк, Луговой, 2007).

Для эффективной работы по развитию данного научного приоритета, кафедра определила следующие основные задачи своей деятельности:

- профессиональная подготовка высококвалифицированного специалиста гуманитарного профиля: конкурентоспособного, обладающего креативным мышлением, владеющего фундаментальными теоретическими знаниями и прикладными навыками в сфере образования;

- организация теоретических и прикладных исследований в целях обеспечения информационно-методической поддержки инновационного образовательного процесса в вузе;

- активное участие в различных научных программах и проектах, поддержанных научными фондами;

- организация педагогического процесса в вузе на основе основных положений Миссии и политики МосГУ с целью развития духовнонравственных, физических и профессиональных качеств личности студента, и, в конечном итоге, социально активной личности (Ситаров, 1988).

Научная школа по педагогическим наукам Московского гуманитарного университета основывается на творческом развитии научного сообщества педагогов под руководством известного ученого, профессора B.А. Ситарова, его научных контактах в рамках всей страны и за ее пределами. В теоретико-методологическом плане научная школа кафедры обосновала ряд концепций, на которых строится дальнейшая научная работа последователей, учеников, новых поколений педагогов-исследователей Московского гуманитарного университета.

В начале 1990-х годов профессор В. А. Ситаров и доктор психологических наук, профессор Череповецкого государственного университета В.Г.Маралов обосновали концепциюпедагогики и психологии ненасилия в образовании, которая успешно реализуется в научно-практической деятельности кафедры. Авторы этой концепции показали пути построения учебного процесса, основанного на принципах ненасилия, представили технологию ненасильственного взаимодействия, обосновали методы формирования способности к ненасилию у всех участников образовательного процесса (Маралов, Ситаров, 2012).

Для эффективного функционирования научной школы необходимо было сформулировать и ответить на два следующих вопроса: в чем заключается уникальность научной школы кафедры педагогики и психологии высшей и что определяет жизнеспособность ее выпускников?

Для определения уникальности подготовки кадров высшей квалификации кафедра основывалась на признании уникальности личности каждого аспиранта, а они, в основном, - это преподаватели вузов, и, соответственно, их уникальный практический педагогический опыт с элементами исследовательской деятельности. Это собственно те научно- 
методические разработки, которые имеются в личном багаже каждого преподаватели и практическое использование которых дает хорошие результаты в образовательном процессе.Поэтому при выборе темы исследования учитывался в первую очередь этот опыт.

В этой связи уникальность подготовки аспирантов, докторантов на кафедре заключается в решении научных проблем на основе интеграции педагогических теорий и личного исследовательского педагогического опыта. Таким образом, подготовка кадров высшей квалификации на основы данного фундаментального положения является приоритетным направлением, которое определяет специфику и особенность научной школы кафедры педагогики и психологии высшей школы. Такое подход определил некоторые направления научных исследований, проводимых под руководством проф. В. А. Ситарова.

Первое направлениенаучных исследований имеет чисто дидактическую направленность. Например, аспирантка Е. Н. Багузина, преподаватель английского языка в Государственном университете управления имела позитивный опыт использования веб-квест технологий в процессе изучения иностранного языка, что и было положено в основу ее исследования «Веб-квест технология как дидактическое средство формирования иноязычной коммуникативной компетентности (на примере студентов неязыкового вуза)» (Багузина, 2011). В результате проведенного исследования был разработан педагогический механизм применения веб-квест технологии в процессе иноязычной подготовки студентов, который заключается в создании микросоциальной учебной сети в рамках выполнения группового веб-проекта. Внедрение веб-квест технологии в обучение иностранному языку позволило на его базе создать целостный дидактический конструкт, включающий уникальную форму обучения, содержание, методы обучения и контроля, и дающий возможность дистанционно управлять самостоятельной учебной деятельность студентов в подготовленной и дидактически сконструированной Интернет-среде, что обеспечивает необходимый процесс погружения студентов в иноязычную информационную среду с одновременным освоением методов поисково-конструктивной работы в ней.

Инновационный вектор был задан процессу восстановительных занятий космонавтов, когда один из инструкторов - М. М. Карелин в процессе своей профессиональной деятельности начал использовать педагогическое тестирование. Эта идея и его личный исследовательский опыт были положены в основу диссертации «Педагогическое тестирование в профессиональной подготовке космонавтов» (Карелин, 2009). Применение педагогического тестирования в процессе профессиональной подготовки космонавтов на основе концептуальных идей классической и современной теории тестирования позволило выстраивать индивидуальную образова- 
тельную программу космонавта для восстановительных занятий.

Учитель математики А. Л. Карасик, пытаясь разрешить противоречие, с которым он сталкивался в процессе своей педагогической деятельности, между возможностями обучаемых наглядно усваивать материал в информационной среде и предлагаемыми им традиционными словеснотекстовыми методами обучения, провел диссертационное исследование на тему «Дидактические особенности обеспечения наглядности обучения средствами информационных технологий» (Карасик, 2007). В результате проведенного исследования было доказано, что внедрение информационных технологий выводит наглядное обучение на качественно новый уровень динамической визуализации обучения, усиливая универсальный характер наглядности как принципа и как метода обучения. Проведенное исследование позволило в процессе преподавания такого сложного математического раздела «стереометрия» обучать учащихся наглядному конструированию собственных вариантов решения учебных задач на основе компьютерного моделирования.

Второе научное направление научных исследований, проводимых под руководством проф. В. А. Ситарова связано с экологическим образованием и воспитанием, поскольку экологическое образование нуждается в постоянно обновлении в связи с существующими и усугубляющимися проблемами, связанными с ухудшением состояния окружающей среды.

Так, например, исследование, проведенное преподавателем биологии в педагогическом колледже Краснодарского края И. А. Полянцевой «Экологическое образование студентов педагогического колледжа на основе принципа природосообразности» (Полянцева, 2005) было посвящено построению экологического образования на основе принципа природосообразности, обосновывающему восстановление естественной связи человека с природой; учитывающего факторы естественного, природного развития человека как существа биологического, развивающегося целостно, по естественным законам и как существа био-социального, на развитие которого оказывает воздействие внешняя среда. И. А. Полянцевой был разработан механизм реализации принципа природосообразности в экологическом образовании студентов, трансформирующий цели, организационные формы и способы взаимодействия субъектов образовательного процесса.

Третье направление научных исследований связано с изучением теории и истории гуманистической педагогики. Концепция гуманистической педагогической традиции была обоснована проф. Л. В. Романюк в 19902000-е годы (Романюк, 1997). Основные положения концепции изложены в монографии «Гуманистическая традиция как историко-педагогический феномен: теоретико-методологический анализ» (Романюк, 2002). 
Основные научные идеи нашли отражение в выполненных под руководством проф. Л. В. Романюк научных исследований.

Так, например, в исследовании Е. В. Шульгиной«Наследие Е. И. Тихеевой как целостная педагогическая система» (Шульгина, 2007), своеобразие которого заключалось в принятии и развитии классической гуманистической педагогической парадигмынаоснове идей К. Д. Ушинского, Л.Н. Толстого, И.-Г. Песталоцци, Ф. Фребеля и других, был показан механизм реализации собственного авторского методы «игры-труда» как вариативной модели организации работы детского сада.

В исследовании О. В. Василенко «Гуманистическая направленность общественно-педагогической деятельности В. Ф. Одоевского» (Василенко, 2007) было представлено целостное видение гуманистической сущности мировоззрения писателя, заключающееся в единстве авторских научно-теоретических взглядов и его общественно-педагогической (филантропической, просветительской, публицистической, литературной и законодательной) деятельности.

Область интересов научной школы Л. В. Романюк связана с развитием гуманистических педагогических традиций. Коллективу ученых (Н.И.Ильинская, О. А. Косинова, И. В. Кощиенко, Г. Н. Скударева, О. А. Чекун, Е. В. Шульгина) удалось получить обобщенные результаты цикла научных работ в области традициологии, провести серию педагогических экспериментов в рамках гуманистической педагогики, музейной педагогики, проанализировать огромное количество научных архивных материалов, изучить опыт работы отечественных педагогов в исторической ретроспективе.

Педагогические традиции Российского зарубежья на территории Китая - одно из историко-педагогических направлений, представленных в научно-исследовательской работе кафедры трудами проф. О. А. Косиновой (Романюк, Косинова, 2012). Среди ее научных работ - монографии «Педагогические традиции российского Зарубежья в Китае в конце XIX - первой половине XX века (1898-1945 гг.)» (Косинова, 2008) и «Образовательные и воспитательные учреждения российского Зарубежья в Китае. Конец XIX - первая половина XX века (1898-1945 гг.)» (Косинова, 2009). В работах О.А. Косиновой раскрываются проблемы интеграции российского зарубежного опыта в современную отечественную педагогическую культуру, межкультурной коммуникации россиян с народами Дальнего Востока в сфере образования, теории и методологии отечественного источниковедения.

Следующим фундаментальным положением, определяющим специфику и особенность научной школы кафедры педагогики и психологии высшей школы является жизнеспособность ее выпускников и, в первую 
очередь, выпускников аспирантуры и докторантуры, которая определяется практико-ориентированной направленностью подготовленных диссертаций с учетом авторитета и узнаваемости научной школы.

И здесь, несомненной является узнаваемость и авторитет, в первую очередь научного руководителя - проф. В. А. Ситарова, под руководством которого успешно защитили докторские и кандидатские диссертации 69 человек, «разбросанные» по территории всей страны и за рубежом. Кроме того, он является автором многих учебных пособий, широко используемых в учебном процессе многих вузов страны. Среди них «Дидактика», «Теория обучения. Теория и практика», «Социальная экология», «Педагогика и психология ненасилия в образовании» и другие. Ученые кафедры публикуют результаты своих научных исследований в различных научных журналах страны, входящих в список журналов, рекомендуемых ВАК: «Знание. Понимание. Умение», «Педагогика», «Вопросы психологии», «Мир образования - образование в мире», «Сибирский педагогический журнал», «AlmaMater (Вестник высшейшколы)», «Международная экономика», «ВестникВятского государственного университета», «Вестник Костромского государственного университета имени Н. А. Некрасова», «Вестник Поморского государственного университета имени М.В. Ломоносова», «Вестник Ставропольского государственного университета», «Вопросы новой экономики», «Вестник экономической безопасности», «Проблемы современного педагогического образования», «Ученые записки университета имени П.Ф. Лесгафта», «Вестник Череповецкого государственного университета», «Образование. Наука. Научные кадры» и другие.

Таким образом, научные приоритеты педагогических работников кафедры охватывают широкий спектр их видения решения этих проблем. Основными векторами исследования стали научные направления: дидактический аспект образовательного процесса; гуманистические традиции как феномен педагогической культуры; педагогическая традициология; российское пореволюционное зарубежье Китая; модели жизненной стратегии российской молодежи; проблемы жизненной среды человека. Анализ приоритетных научных направлений кафедры позволяет сделать вывод о соблюдении логической последовательности подготовки кадров высшей квалификации.

\section{СПИСОК ЛИТЕРАТУРЫ}

Багузина, И. И. (2011) Веб-квест технология как дидактическое средство формирования иноязычной коммуникативной компетентности : на примере студентов неязыкового вуза : дисс.... кандидата педагогических наук. М. 238 с.

Василенко, О.В.(2007)Гуманистическая направленность Общественно- 
педагогической деятельности В. Ф. Одоевского : дисс. ... канд. пед. н. 158 с. Ильинский, И. М. (1995) Концепция воспитания жизнеспособных поколений. М. : Институт молодежи.

Ильинский, И. М. (2001) Молодежь и молодежная политика. М. : Голос. 692 c.

Карасик, А. Л. (2007) Дидактические особенности обеспечения наглядности обучения средствами информационных технологий : дисс.... канд. пед. н. М. 234 с.

Карелин, М. М. (2009) Педагогическое тестирование в профессиональной подготовке космонавтов : автореф. дисс. ... канд. пед. н. М. 18 с.

Косинова, О.А. (2008) Педагогические традиции российского зарубежья в Китае в конце XIX - первой половине XX веков (1898-1945 гг.). М. : [б. и.]. 200 с.

Косинова, О. А. (2009) Образовательные и воспитательные учреждения российского Зарубежья в Китае. Конец XIX - первая половина XX веков (1898-1945 гг.). М. 160 с.

Маралов, В. Г., Ситаров, В. А. (2012) Педагогика и психология ненасилия в образовании : учебное пособие для бакалавров. 2-е изд. М. : Юрайт. 424 c.

Полянцева, И. А. (2005) Экологическое образование студентов педагогического колледжа на основе принципа природосообразности : дисс. ... канд. пед. наук. М. 242 с.

Романюк, Л. В. (1997) Проблема гуманизма в русской педагогике второй половины XIX века : дисс. ... канд. пед. н. М. 140 с.

Романюк, Л. В. (2002) Гуманистическая традиция как историкопедагогический феномен: теоретико-методологический анализ. Киров : ВГПУ. 116 с.

Романюк, Л. В., Косинова, О. А. (2012) Российское педагогическое зарубежье // Знание. Понимание. Умение. № 4. С. 330-333.

Ситаров, В. А. (1988) Психолого-педагогические проблемы формирования социально-активной личности : учебное пособие к спецкурсу. М. : МГПИ им. В. И. Ленина. 68 с.

Ситаров, В. А., Романюк, Л. В., Луговой, М. В. (2007) Жизнеспособность «Концепция воспитания жизнеспособных поколений» // Сибирский педагогический журнал. № 1. С. 134-137.

Дата поступления: 12.12.2016 г.

Ситаров Вячеслав Алексеевич - доктор педагогических наук, профессор, заведующий кафедрой педагогики и психологии высшей школы Московского гуманитарного университета. Адрес: 111395, Россия, г. Москва, ул. Юности, д. 5. Тел.: +7 (495) 374-74-59. Эл. адрес: sitarov@mail.ru 
Романюк Лариса Валеръевна - доктор педагогических наук, профессор, проректор по научной работе Московского гуманитарного университета. Адрес 111395, Россия, г. Москва, ул. Юности, д. 5. Тел.: +7 (495) 374-58-81. Эл. адрес: lromanyuk@mosgu.ru

Sitarov Viacheslav Alekseevich, Doctor of Pedagogy, Professor and Chair, Department of Pedagogy and Psychology of Higher School, Moscow University for the Humanities. Postal address: 5 Yunosti St., 111395 Moscow, Russian Federation. Tel.: +7 (495) 374-74-59. E-mail: sitarov@mail.ru

Romaniuk Larisa Valer'evna, Doctor of Pedagogy, Professor, Vice-rector for research, Moscow University for the Humanities. Postal address: 5 Yunosti St., 111395 Moscow, Russian Federation. Tel.: +7 (495) 374-58-81. E-mail: lromanyuk@mosgu.ru

\section{Для цитирования:}

Ситаров В. А., Романюк Л. В. Научные приоритеты кафедры педагогики и психологии высшей школы Московского гуманитарного университета [Электронный ресурс] // Научные труды Московского гуманитарного университета. 2016, № 6. URL: journals.mosgu/trudy/article/view/386 (дата обращения: дд.мм.гг.). 